\title{
Landscape Analysis Over 30 Years to Assess the Impact of River Damming On Natural Ecosystem
}

\author{
Hasti Andon Petrosians ${ }^{1}$, Afshin Danehkar ${ }^{2}$, Ali Akbar Nazari Samani² ${ }^{2}$ and Naser \\ Mashahadi $^{2}$ \\ ${ }^{1}$ University of Tehran \\ ${ }^{2}$ Tehran University
}

May 5, 2021

\begin{abstract}
Although there are considerable profits in dam projects, they contribute to significant environmental changes. Landscape patterns are influenced by human pressure and are altered continuously. This study investigated the changes in the landscape pattern of Jask's coastal area in Iran due to the Jagin River dam's construction. A proposed methodology employed satellite images from 1987 to 2018 and classified them by multiple approaches to make LULC maps. Eight information categories were evaluated after classification. The accuracy of the classification was determined using the error matrix and kappa index. FRAGSTATS software was applied to calculate several landscape metrics such as edge density (ED), largest patch index (LPI) and Shannon's diversity index (SHDI). The study reported that water right especially in the recent years, because of excessive use of reserve water, decreased and downstream of Jagin River was dried. The landscapes were continuously characterized by anthropogenic pattern features (agriculture land, aquaculture land, built-up land and residential land) after the dam's construction. Rangeland cover and riparian vegetation decreased, and agriculture land increased with in filling pattern. The sand dune area has been spread to the residential area and roots of mangrove forests, because of this reason some parts of mangrove forest dried and roads are covered by sand dune. Their temporal comparison allowed us to localize the change in landscape patterns under the study time. The results can help decision-makers to evaluate the net benefits acquired as a result of the dam projects.
\end{abstract}

\section{Introduction:}

Land cover generally has a close correlation with human activities and the physical environment. Its interaction with physical, ecological, geomorphic and anthropogenic processes is significant and they can change it drastically. Between all the mentioned factors, anthropogenic is a critical factor that causes some changes in land cover and land-use (Singh et al., 2017). Detection of LULC change of the Earth's surface is extremely important for any kind of sustainable development program and helps to provide a solution for social, economic and environmental problem(El-kawy, Rød, Ismail, \& Suliman, 2011)

The spatial structure and form of landscape components are considered as Landscape patterns. Land-cover and land-use change (LCLUC) alters landscape patterns and affects regional ecosystems(Zhang, Kung, \& Johnson, 2017).Landscape patterns concept have been reflected in several different subjects such as land-use change, urban planning, environmental protection, ecological construction and policy making continuously. Over the past three decades, the study of the spatiotemporal patterns of landscape has been one of the most critical hotspot research subjects(Gustafson, 2019 ; Feng et al., 2018). Landscape ecologists might be unable to detect landscape pattern attributes such as habitat provision or soil degradation if pattern measurement limits to a few points within a land-cover sequence ( Feng et al., 2018).

In the analysis of landscape patterns during a time, landscape-level and class level metrics can be applied 
to evaluate the human impacts on the natural ecosystems (Singh et al., 2017) In this regard, remote sensing (RS), geographical information systems (GIS), land-use models, and statistical methods would be employed for landscape patterns analysis. Landscape metrics are widely used to detect and measure the spatiotemporal change of landscape patterns and represents the landscape complexity (Feng et al., 2018)

Coastal ecosystems have exceptional ecological and economic values (Zang, Zou, Song, \& Yao, 2019). Unfortunately, during recent decades, these ecosystems are impacted by various ecological and human factors, especially in coastal areas where urbanization is rapid and natural hazards are expected (Pak \& Farajzadeh, 2007). Therefore, analyzing the spatiotemporal changes and their influencing factors (especially human factors) in the distribution of coastal wetland natural features presents valuable data for practical conservation, sustainable development and implementing ICZM (Zang et al., 2019).

Construction of a dam on the rivers is one of the most important developments, which has a significant effect on the most parts of Iran as an arid country. Construction dam causes several concerns, including desertification, land degradation; land fragmentation, development of agriculture land, increasing immigrant population, and above all, the decline in river discharge to the downstream area. Hence, obviously it has an impact on river flow regimes and natural wetlands( $\mathrm{Lu}, 2018)$.

After the industrial revolution and because of political decisions, Iran's coastal area, especially in Jask city, has experienced the non-planned and extensive development in infrastructures building such as dams, dikes, canals, breakwaters and settlements. This development has created a rapid change in land cover and landscape patterns(Pak \& Farajzadeh, 2007) and landscapes are under enormous pressures. This continuous and noticeable development influences on natural resources over the past three decades.

In the coastal area of Jask city, there is one important seasonal river, Jagin River. A dam was constructed between 2002 and 2007 on its upstream. This dam has a crucial role in controlling floods downstream and providing the agricultural water. Because of that, agriculture lands increases in the fertile soils of the flat river floodplains. However, similar to the other dam construction projects, this project has caused environmental and ecological problems, which has not been ever discussed openly compared to their benefits.

In these parts of Iran, natural mangrove forests extend as one of the most productive coastal ecosystems that provide natural nursery habitats for a wide variety of prawns, shrimp, fish, crabs, and other crustaceans. Additionally, the rural community life entirely depends on mangroves services and products, such as supplying fuel-wood, aquatic products, medicinal herbs and fodder for domestic animals(Petrosian, Kar, Ashrafi, \& Feghhi, 2016).

Each river is unique in terms of its flow patterns, the landscapes it flows through, and the species it supports, this implying that dam impacts on the river are also unique. (Operations et al., 2000). With these in mind, this study mainly focuses on analyzing the changes in landscape patterns located downstream of the Jagin River dam to have a better understanding of environmental impact of this dam on the downstream ecosystem. To achieve this objective, various spatial and non-spatial data of three periods (31 years) are applied to provide LULC maps for landscape change detection: 1987 and 1997 represent pre-construction time, 2003 represent the time of construction and 2008, 2014 and 2018 represent post-construction periods of the reservoir. Providing historical LULC help to determine the reasons for the changes through spatial comparison of produced LULC maps(El-kawy et al., 2011).

Many researchers studied LULC change over a long time. Kawy and his colleague made recent and historical LULC maps to find the trend of changing in the western Nile delta of Egypt for 22 years(El-kawy et al., 2011). Quyang and his colleague used analyzed the spatial-temporal landscape characteristics from 1977 to 2006 in a part of the Yellow River basin(Ouyang, Skidmore, Hao, Toxopeus, \& Abkar, 2009). Iwuji and his colleague investigated land use dynamics associated with a Mbaa River dam by using GIS and RS (M. C. Iwuji , C. P. Iheanyichukwu, J. D. Njoku, F. I. Okpiliya, S. O. Anyanwu, 2017) (M. C. Iwuji, C. P. Iheanyichukwu, J. D. Njoku, F. I. Okpiliya, S. O. Anyanwu, 2017). Zhao and his colleague studied the spatial-temporal change of land use within three buffer distances from Lancang River dam centre during 1974, 1991 and 2004 to investigate effects of dam on LULC change(Zhao et al., 2010).Liu and his colleague quantified Forest pattern 
dynamics based on landscape metrics after dam construction in the Lancang River, China.(Liu \& Wang, 2014)

In summary, the study aims to:

1. Analyze the responses of the landscape pattern of the coastal and wetland areas in Iran to the dam construction, by emphasizing on sand dunes and natural vegetation cover.

2. Examine the spatiotemporal variation of landscape patterns in Jask coastal area between 1987 and 2018

The study's primary goal is to provide stakeholders and decision-makers with the consequences of the dam construction on the natural ecosystem. Moreover, this study presents scientific knowledge for developing ecological management strategies and plans for dam operation, which can lead to the protection of downstream natural ecosystems and local people's lives.

Materials and Methods

Our study area is located south of Iran in the Hormozgan province coastal area (a part of the Oman sea coastal area),located from 25deg 30' to25deg 51' $\mathrm{N}$ and 57deg 55' to 58deg 22' E. The area is about 77717.51 ha. This part of the coastal area is located directly southward of Jagin River and receives freshwater from this river in the rainy months. Accordingly, Jagin River plays a critical role in the water cycle, sediment cycle, energy balance and ecological development for this part of the coastal area. This river is seasonal and exhibits seasonal variability in the water level and area (Acreman, 2014; Wohl \& Brian, 2015). Jagin River also discharges freshwater to the mangrove forest natural habitats (Andr et al., 2020) analyze land cover's changes over 31 years, six Landsat satellite images of different years (1987, 1997, 2003, 2008, 2014 and 2018) were selected., even though Landsat satellites have low spatial resolution sensors, they offer an unlimited source of information (Hu, Huang, Du, Han, \& Wang, 2015) The Landsat satellite data have been downloaded from the United States Geological Survey (USGS) official website (http://www.usgs.gov). Satellite data, including TM, ETM+, and OLI sensors, and all the downloaded images were taken from the same month (July). The geometric and atmospheric corrections of all downloaded satellite images were carried out similar to the previous presented approaches (Wu et al., 2017).

\section{Landscape Classification}

Land cover and land use information are primary indicators utilized to assess environmental processes quantitatively(Sudhakar Reddy, Manaswini, Jha, Diwakar, \& Dadhwal, 2017) . The low spectral resolution of satellite data restricts the application of automated classification techniques(Hu et al., 2015) . Recent researches have shown that the integration of different classification methods enhances the quality and accuracy of a Landsat land cover classification. In this study, we used a Multiple (Hybrid) Classifier Approach to classify satellite images and provide land cover classification maps (Cai, Li, Ye, \& Zhang, 2016). Firstly, satellite images were classified by the Maximum likelihood method and Support vector machine (SVM) using ENVI 4.8. The results of the first classification were not satisfactory. Therefore, Object-based classifiers and pixel-based classifiers were applied to identify LCLU categories simultaneously. For the object-based classification, available aerial photos, google earth and field survey data were used.

Since the rasterization method and spatial resolutions influence negatively on geographical data, vector basis maps were adopted to estimate LCLU changes and all maps were converted to a vector format to calculate the indices(Feng et al., 2018).

The definition of the land use and land cover categories depends on the USGS and Anderson's LCLU classification system (Tran \& Fischer, 2017; Feng et al., 2018 ; Dong \& Wang, 2010). These maps provide spatially explicit data to evaluate the changes over 30 years. As mentioned previously, interactions between the developed area (like agriculture land and buildup land) and natural area (like vegetation cover) are the focus of this paper. The classified images of 1987 and 2018 were overlaid to produce a transition table, demonstrating the LULC transition between 1987 and 2018. The diagonals of this table indicate the number 
of land use classes that were remained constant during that period, while the off-diagonal entries accounted for a transition from one class to another class(Zewdie \& Csaplovics, 2016).

Accuracy Assessment

In this study, time is one of the significant obstacles since it is impossible to measure past time accuracy. As a result, accuracy assessment was performed by both infield and outfield accuracy assessments. The outfield assessment was done by taking a training sample from reference images (Google Earth and aerial photos). The infield assessment was done during field survey (Haque \& Basak, 2017) For estimating classification accuracy, a minimum of 50 samples per class is recommended for maps with less than a dozen classes. Therefore, in this study, 50 Random points were used for (Muller et al., 1998; Wulder, Franklin, \& White, 2006 ) calculating overall accuracy and Kappa index.

\section{Landscape Metrics Analysis}

To quantify landscape patterns and analyze landscape dynamics, in the first step, we reviewed 21 related articles (Cai, Li, Ye, \& Zhang, 2016), (Sudhakar Reddy, Manaswini, Jha, Diwakar, \& Dadhwal, 2017), (Mahamane, Hochschild, Schultz, \& Kuma, 2015), (Feng et al., 2018), (Tran \& Fischer, 2017), (Dong \& Wang, 2010),(Vaz, 2014) , (Manson, Loneragan, \& Phinn, 2003), (Singh et al., 2017), (Ju, Arnaldo, Gomes, Fontes, \& Mcmanus, 2017),(Sinha, Kumar, \& Reid, 2016), (Alphan, 2017), (Gbanie, Griffin, \& Thornton, 2018) , (Deng, Wang, Hong, \& Qi, 2009),(Basin, 2018), (Chen, Jia, Hutjes, \& Menenti, 2015),(Araya \& Cabral, 2010), (Zhao et al., 2010), (Botequilha-Leitao \& Diaz-Varela, 2018), (Narumalani, Mishra, \& Rothwell, 2004) , (Xu \& Min, 2013) and found 8 landscape metrics were more emphasized. In the second step, indicated landscape metrics were calculated at the landscape and class levels by FRAGSTATS 3.3 (Feng et al., 2018; Wu et al., 2017) . Table 1 shows the landscape pattern indices applied in this study. We used McGarigal approach in definition landscape metrics conception.

Table 1: Landscape metrics, groups and abbreviation used in this study (Reading, 2001; Feng et al., 2018; States, Nrothwest, \& Technical, 1995)

\begin{tabular}{|c|c|c|c|c|c|}
\hline Level & $\begin{array}{l}\text { Landscape } \\
\text { Metric }\end{array}$ & Abbreviation & Formula & Metric(unit) & Range \\
\hline \multirow[t]{8}{*}{ Class } & Class Area & $\mathrm{CA}$ & \multirow{5}{*}{$\begin{array}{l}\sum_{i=1}^{n} \operatorname{aik}\left(\frac{1}{10000}\right) \\
N P=n i \\
L P I= \\
\frac{\max \text { aik }}{A}(100) \\
M P= \\
\frac{\sum_{i=1}^{n} \text { aik }}{\text { ni }}\left(\frac{1}{10000}\right) \\
P D=\frac{\text { ni }}{A}(100)\end{array}$} & Hectare & $\begin{array}{l}\mathrm{CA}>0, \\
\text { without limit }\end{array}$ \\
\hline & $\begin{array}{l}\text { Number of } \\
\text { Patches }\end{array}$ & NP & & - & $\begin{array}{l}\mathrm{NP}[?] 1, \\
\text { without limit }\end{array}$ \\
\hline & $\begin{array}{l}\text { Largest Patch } \\
\text { Index }\end{array}$ & LPI & & $\%$ & $\begin{array}{l}0<\text { LPI [?] } \\
100\end{array}$ \\
\hline & $\begin{array}{l}\text { Mean Patch } \\
\text { Size }\end{array}$ & MPS & & Hectare & $\begin{array}{l}\text { MPS[?] } 0 \text {, } \\
\text { without limit }\end{array}$ \\
\hline & Patch Density & $\mathrm{PD}$ & & $\begin{array}{l}\text { Number per } \\
100 \text { hectare }\end{array}$ & $\begin{array}{l}\mathrm{PD}[?] 0, \\
\text { without limit }\end{array}$ \\
\hline & $\begin{array}{l}\text { Landscape } \\
\text { Shape Index }\end{array}$ & LSI & & - & $\begin{array}{l}\text { LSI [?] } 1 \text {, } \\
\text { without limit }\end{array}$ \\
\hline & & \multicolumn{4}{|c|}{$L S I=\frac{0.25 * \sum_{i=1}^{n} \mathrm{eik}}{\sqrt{A}}$} \\
\hline & Edges Density & ED & $\begin{array}{l}E D= \\
\frac{\sum_{i=1}^{n} \text { eik }}{A}(10000)\end{array}$ & $\begin{array}{l}\text { Meters per } \\
\text { hectare }\end{array}$ & $\begin{array}{l}\mathrm{ED}[?] 0, \\
\text { without limit }\end{array}$ \\
\hline
\end{tabular}




\begin{tabular}{|c|c|c|c|c|c|}
\hline Level & $\begin{array}{l}\text { Landscape } \\
\text { Metric }\end{array}$ & Abbreviation & Formula & Metric(unit) & Range \\
\hline Landscape & $\begin{array}{l}\text { Shannon's } \\
\text { Diversity } \\
\text { Index }\end{array}$ & SHDI & $\begin{array}{l}S H D I= \\
\sum_{i=1}^{m}(P i * \ln P i)\end{array}$ & - & $\begin{array}{l}\text { SHDI[?] } 0, \\
\text { without limit }\end{array}$ \\
\hline
\end{tabular}

$\mathrm{a}_{\mathrm{ij}}=\quad \operatorname{area}\left(\mathrm{m}^{2}\right)$ of patch $\mathrm{ij}$

$\mathrm{ni}=$ number of patches in the landscape of patch type (class) i

$\mathrm{P}_{\mathrm{i}}=$ proportion of the landscape occupied by patch type (class) $\mathrm{i}$

$\mathrm{A}=$ total landscape area $\left(\mathrm{m}^{2}\right)$

$\mathrm{e}_{\mathrm{ik}}=$ total length $(\mathrm{m})$ of edge in landscape involving patch type (class) i; includes landscape boundary and background segments involving patch type i.

\section{Field Survey}

A short field survey was conducted in 2019 August. The geographic coordinate's data recorded by GPS are used as reference data of landscape classification to check the accuracy.

The field survey helped to understand the natural setting of the study area. Short interviews with local people, especially the older ones, and with natural resource organization of study area (Jask City) were conducted. These interviews served to understand the perception of land-use trends and land cover change (emphasize on time after dam construction) and gave us a better sense of government actions relevant to mangrove forest conservation area and water right.

\section{Results}

Georeferenced images were classified. Classification results are given in Figure 2. The total accuracy values of satellite images of 1987,1997,2003,2008, 2014, 2018 are given as 93.44\%, 93.33\%,95.24\%, 95.0\%, $96.8 \%, 95.1 \%$, respectively, and therefore, the calculated kappa statistics are $0.76,0.74,0.83,081,0.88,0.82$, respectively, which derived from Table 2.

Eight main land cover types were identified, including Agriculture Land, Aquaculture Land, Mixed Build up Land, Sandy area- Dune, Forest Wetland-Mangrove Forest, Riparian Vegetation, Built-up Land Residential and Rangeland.

The detailed result of landscape metrics in landscape class is provided in Table 3 and

Table 2: Accuracy Assessment Result of Classified Images

\begin{tabular}{lllllll}
\hline & 1987 & 1997 & 2003 & 2008 & 2014 & 2018 \\
\hline Total Accuracy & $93.44 \%$ & $93.33 \%$ & $95.24 \%$ & $95 \%$ & $96.8 \%$ & $95.1 \%$ \\
Kappa Index & 0.76 & 0.74 & 0.83 & 0.81 & 0.88 & 0.82 \\
\hline
\end{tabular}

Table 3: Result of Analysis Landscape Metrics (Class-Level)

\begin{tabular}{llllllll}
\hline $\mathbf{2 0 1 8}$ & $\mathbf{2 0 1 4}$ & $\mathbf{2 0 0 8}$ & $\mathbf{2 0 0 3}$ & $\mathbf{1 9 9 7}$ & $\mathbf{1 9 8 7}$ & Class level & Metric \\
\hline 8123.8 & 7104.83 & 6933.6 & 19.08 & 13.77 & 13.21 & Agriculture Land & CA \\
473.34 & 450.28 & 439.78 & 136.2 & 0 & 0 & Aquaculture Land & \\
5919.35 & 5890.63 & 5886.78 & 5980.82 & 5401.82 & 5334.74 & Sandy area- Dune & \\
610.98 & 606.18 & 542.39 & 483.18 & 492.9 & 467.25 & Forest Wetland-Mangrove Forest
\end{tabular}




\begin{tabular}{|c|c|c|c|c|c|c|c|}
\hline 2018 & 2014 & 2008 & 2003 & 1997 & 1987 & Class level & Metric \\
\hline 915.71 & 909.51 & 799.5 & 668.07 & 533.99 & 512.14 & Built up Land-Residential & \\
\hline 3457.7 & 4192.141 & 4511.461 & 3598.76 & 4486 & 4490.41 & Riparian Vegetation & \\
\hline 4814.92 & 4929.56 & 5972.76 & 5314.84 & 6950.95 & 7026.86 & Rangeland & \\
\hline 578.8 & 564.61 & 0 & 0 & 0 & 0 & Mixed Build up Land & \\
\hline 39 & 39 & 15 & 2 & 2 & 2 & Agriculture Land & NP \\
\hline 2 & 2 & 2 & 1 & 0 & 0 & Aquaculture Land & \\
\hline 25 & 24 & 23 & 22 & 22 & 20 & Sandy area- Dune & \\
\hline 15 & 15 & 15 & 18 & 16 & 16 & Forest Wetland-Mangrove Forest & \\
\hline 7 & 6 & 5 & 5 & 2 & 2 & Built up Land-Residential & \\
\hline 17 & 17 & 15 & 15 & 17 & 17 & Riparian Vegetation & \\
\hline 74 & 71 & 68 & 47 & 51 & 53 & Rangeland & \\
\hline 4 & 3 & 0 & 0 & 0 & 0 & Mixed Build up Land & \\
\hline 208.32 & 182.19 & 46.26 & 9.6 & 7 & 6.6 & Agriculture Land & MPS \\
\hline 236.09 & 219.97 & 219.56 & 136.2 & 0 & 0 & Aquaculture Land & \\
\hline 216.57 & 215.76 & 214.48 & 246.43 & 204.53 & 187.26 & Sandy area- Dune & \\
\hline 39.39 & 38.20 & 36.18 & 26.85 & 31.84 & 29.21 & Forest Wetland-Mangrove Forest & \\
\hline 132.45 & 150.29 & 160.10 & 133.74 & 267.27 & 256.35 & Built up Land-Residential & \\
\hline 235.99 & 259.51 & 300.62 & 220.49 & 225.93 & 213.35 & Riparian Vegetation & \\
\hline 64.71 & 69.77 & 98.04 & 126.58 & 131.47 & 132.9 & Rangeland & \\
\hline 144.05 & 191.51 & 0 & 0 & 0 & 0 & Mixed Build up Land & \\
\hline 2.41 & 2.09 & 0.46 & 0.039 & 0.036 & 0.036 & Agriculture Land & ED \\
\hline 0.93 & 0.91 & 0.9 & 0.44 & 0 & 0 & Aquaculture Land & \\
\hline 3.83 & 3.80 & 3.73 & 3.69 & 3.82 & 3.8 & Sandy area- Dune & \\
\hline 0.72 & 0.73 & 0.74 & 0.75 & 0.73 & 0.76 & Forest Wetland-Mangrove Forest & \\
\hline 0.53 & 0.5 & 0.44 & 0.44 & 0.34 & 0.32 & Built up Land-Residential & \\
\hline 3.41 & 3.59 & 3.76 & 3.07 & 3.44 & 3.26 & Riparian Vegetation & \\
\hline 4.16 & 3.90 & 3.81 & 3.56 & 3.83 & 3.9 & Rangeland & \\
\hline 0.25 & 0.23 & 0 & 0 & 0 & 0 & Mixed Build up Land & \\
\hline 5.9 & 5.7 & 0.54 & 0.013 & 0.011 & 0.011 & Agriculture Land & LPI \\
\hline 0.4 & 0.38 & 0.36 & 0.17 & 0 & 0 & Aquaculture Land & \\
\hline 1.33 & 1.31 & 1.29 & 1.28 & 1.25 & 1.22 & Sandy area- Dune & \\
\hline 0.27 & 0.27 & 0.26 & 0.24 & 0.24 & 0.23 & Forest Wetland-Mangrove Forest & \\
\hline 0.60 & 0.6 & 0.6 & 0.5 & 0.41 & 0.4 & Built up Land-Residential & \\
\hline 2.99 & 3.2 & 3.26 & 1.67 & 1.7 & 1.66 & Riparian Vegetation & \\
\hline 2.8 & 3 & 3.9 & 3.9 & 5.1 & 5.13 & Rangeland & \\
\hline 0.74 & 0.72 & 0.036 & 0 & 0 & 0 & Mixed Build up Land & \\
\hline 5.20 & 4.81 & 3.45 & 1.88 & 1.76 & 1.6 & Agriculture Land & LSI \\
\hline 8.22 & 8.50 & 8.65 & 7.31 & 0 & 0 & Aquaculture Land & \\
\hline 10.32 & 10.18 & 9.89 & 9.74 & 10.60 & 10.72 & Sandy area- Dune & \\
\hline 5.65 & 5.82 & 6.20 & 6.84 & 6.64 & 6.6 & Forest Wetland-Mangrove Forest & \\
\hline 3.41 & 3.28 & 3.05 & 3.32 & 2.86 & 2.8 & Built up Land-Residential & \\
\hline 10.09 & 10.52 & 10.74 & 10.68 & 10.85 & 10.55 & Riparian Vegetation & \\
\hline 9.90 & 9.60 & 9.58 & 9.51 & 9.2 & 8.93 & Rangeland & \\
\hline 2.02 & 1.91 & 0 & 0 & 0 & 0 & Mixed Build up Land & \\
\hline 0.05 & 0.05 & 0.02 & 0.002 & 0.002 & 0.002 & Agriculture Land & $\mathrm{PD}$ \\
\hline 0.002 & 0.002 & 0.002 & 0.001 & 0 & 0 & Aquaculture Land & \\
\hline 0.032 & 0.03 & 0.029 & 0.028 & 0.028 & 0.025 & Sandy area- Dune & \\
\hline 0.019 & 0.019 & 0.019 & 0.023 & 0.02 & 0.02 & Forest Wetland-Mangrove Forest & \\
\hline 0.009 & 0.007 & 0.006 & 0.006 & 0.002 & 0.002 & Built up Land-Residential & \\
\hline 0.02 & 0.02 & 0.019 & 0.019 & 0.02 & 0.02 & Riparian Vegetation & \\
\hline
\end{tabular}




\begin{tabular}{llllllll}
\hline $\mathbf{2 0 1 8}$ & $\mathbf{2 0 1 4}$ & $\mathbf{2 0 0 8}$ & $\mathbf{2 0 0 3}$ & $\mathbf{1 9 9 7}$ & $\mathbf{1 9 8 7}$ & Class level & Metric \\
\hline 0.095 & 0.091 & 0.087 & 0.06 & 0.065 & 0.069 & Rangeland \\
0.005 & 0.003 & 0 & 0 & 0 & 0 & Mixed Build up Land & \\
\hline
\end{tabular}

The landscape index of the study area on the landscape pattern level is shown in Table 4 for the study period.

Table 4: Result of Analysis a Landscape Metric (Landscape-Level)

\begin{tabular}{lllllll}
\hline $\mathbf{2 0 1 8}$ & $\mathbf{2 0 1 4}$ & $\mathbf{2 0 0 8}$ & $\mathbf{2 0 0 3}$ & $\mathbf{1 9 9 7}$ & $\mathbf{1 9 8 7}$ & Metric \\
\hline 1.116 & 1.097 & 1.119 & 0.782 & 0.835 & 0.830 & SHDI \\
\hline
\end{tabular}

Table 5 shows quantification of land cover area changes (CA) between 1987 and 2018, based on the transitions matrix

Table 5: The transition matrix from 1987 to 2018

\begin{tabular}{|c|c|c|c|c|c|c|c|c|c|}
\hline $\begin{array}{l}\text { Initial } \\
\text { state } \\
(1987) \\
\text { Area(ha) }\end{array}$ & $\begin{array}{l}\text { Initial } \\
\text { state } \\
(1987) \\
\text { Area(ha) }\end{array}$ & $\begin{array}{l}\text { Initial } \\
\text { state } \\
(1987) \\
\text { Area(ha) }\end{array}$ & $\begin{array}{l}\text { Initial } \\
\text { state } \\
(1987) \\
\text { Area(ha) }\end{array}$ & $\begin{array}{l}\text { Initial } \\
\text { state } \\
(1987) \\
\text { Area(ha) }\end{array}$ & $\begin{array}{l}\text { Initial } \\
\text { state } \\
(1987) \\
\text { Area(ha) }\end{array}$ & $\begin{array}{l}\text { Initial } \\
\text { state } \\
(1987) \\
\text { Area(ha) }\end{array}$ & $\begin{array}{l}\text { Initial } \\
\text { state } \\
(1987) \\
\text { Area(ha) }\end{array}$ & $\begin{array}{l}\text { Initial } \\
\text { state } \\
(1987) \\
\text { Area(ha) }\end{array}$ & $\begin{array}{l}\text { Initial } \\
\text { state } \\
(1987) \\
\text { Area(ha) }\end{array}$ \\
\hline \multirow[t]{10}{*}{$\begin{array}{l}\text { Final } \\
\text { state(2018) } \\
\text { Area (ha) }\end{array}$} & & Aquacultur & $\begin{array}{l}\text { eAgriculture } \\
\text { Land }\end{array}$ & $\begin{array}{l}\text { Barren } \\
\text { Land }\end{array}$ & $\begin{array}{l}\text { Build up } \\
\text { Land- } \\
\text { Residential }\end{array}$ & $\begin{array}{l}\text { Mangrove } \\
\text { Forest }\end{array}$ & $\begin{array}{l}\text { Mixed } \\
\text { Build up } \\
\text { Land }\end{array}$ & Rangeland & $\begin{array}{l}\text { Riparian } \\
\text { Vegetation }\end{array}$ \\
\hline & Aquaculture & & 0 & 473.34 & 0 & 0 & 0 & 0 & 0 \\
\hline & $\begin{array}{l}\text { Agriculture } \\
\text { Land }\end{array}$ & & 13.21 & 5793.77 & 0 & 0 & 0 & 1905.34 & 411.48 \\
\hline & $\begin{array}{l}\text { Barren } \\
\text { Land }\end{array}$ & 0 & 0 & 51514.65 & 0 & 20.19 & 0 & 155.19 & 621.23 \\
\hline & $\begin{array}{l}\text { Build } \\
\text { up } \\
\text { Land- } \\
\text { Residential }\end{array}$ & 0 & 0 & 352.26 & 512.14 & 0 & 0 & 32.77 & 0 \\
\hline & $\begin{array}{l}\text { Forest } \\
\text { Wetland- } \\
\text { Mangrove } \\
\text { Forest }\end{array}$ & 0 & 0 & 163.92 & 0 & 447.0 & 0 & 0 & 0 \\
\hline & $\begin{array}{l}\text { Mixed } \\
\text { Build } \\
\text { up } \\
\text { Land }\end{array}$ & 0 & 0 & 50.22 & 0 & 0 & 0 & 10 & 0 \\
\hline & Rangeland & 0 & 0 & 0 & 0 & 0 & 0 & 4814.92 & 0 \\
\hline & $\begin{array}{l}\text { Riparian } \\
\text { Vegetation }\end{array}$ & 0 & 0 & 0 & 0 & 0 & 0 & 0 & 3457.7 \\
\hline & $\begin{array}{l}\text { Sandy } \\
\text { area- } \\
\text { Dune }\end{array}$ & 0 & 0 & 1524.74 & 0 & 0 & 0 & 108.64 & 0 \\
\hline
\end{tabular}




\section{Discussion}

Comparison based on a single metric cannot provide enough information for a comprehensive assessment of environmental change (Wu et al., 2017), so we analyzed different metrics for each land use and land cover classes separately as below:

Agriculture land: As it can be seen from the maps and from the landscape metrics analysis (Table 3). CA, NP, PD, MPS, ED, LPI and LSI metrics of agriculture land class increased. The total area of agricultural land increased by 8110.59 ha in 31 years. The main aim of the dam is to provide water for farmers and irrigated agriculture lands. Accordingly, most of the agriculture lands have been added after construction of dam, between 2008 and 2014.

Based on the field survey, watermelon is the dominant plant that grows in the study area. This vegetable needs high Crop Water Productivity (CWP) (Rashidi \& Gholami, 2008) and it's not an intelligent choice for the south of Iran with a high scarcity of water.

MPS dramatically increased over time. It shows that some patches around agriculture area converted to agriculture lands and merged to neighbors' patches. In other words, filling pattern rather than frog development was the norm. LPI increased by time and it showed centralized area development. ED increased (almost by $65 \%$ ). ED is associated with the total landscape edge and should increase with new nuclei but may decline as some polygons merge, and therefore, there would be no clear boundary between patches (Saura, S., \& Martinez-Millan, 2001) The upward trend of this metric during 1987 and 2018 is the signs of increasing patches especially with linear dimensions (Li, Zhu, Sun, \& Wang, 2010). The increasing of LSI highlights the fact that the shapes of the patches have become more complex (Steinhardt \& Lehmann, 2001)

Aquaculture: During 1997 and 2018, the area of aquaculture land increased considerably. The development of shrimp aquaculture was causing pressure on the coastal environment (Pa, 2005) According to the increasing trend of MPS, ED and LPI and constant trend of NP and PD, the development pattern of aquaculture land was infilling. The LSI decreased during the period of study and illustrated that the shape of aquaculture land had become simpler and more irregular, such as squares or circles Figure 3 demonstrates the temporal transitions of land use classes in the period 1987-2018 (Moser, Zechmeister, Plutzar, Sauberer, \& Grabherr, 2002).

Figure 3: Temporal transitions of LULC classes between 1987 and 2018

Sand dune: Except for a small decrease from 2003 to 2014, sand dune areas increased from 1987 to 2018. The primary cause of the decline in the sand dune area was the land-use change, that with in this change, sand dunes was removed and was replaced with build-up land, especially commercial seaport (Table 5). Except for a decreasing MPS from 2003 to 2008, this metric increased during the study period. Simultaneous Increase in NP, PD, MPS implied that either new erg added with a larger size or older dunes had centralized expansion. Considering it with a high LPI level, these results suggest that this class is undergoing centralization over time. The increase in ED and LSI from 2003 to 2018 illustrated that the new patches had more complex geometric forms and edges.

Based on the field survey, sand dune extended to roads, oases and irrigation channels and natural mangrove forest areas (Figure 4 ). Besides, they are very close to the residential area and there is a high risk that residential area would be buried (Figure 5) and the life of local people can be affected.

Recent studies showed that source of coastal sand dune in Jask is Jagin River in two different ways:

1. Transporting a high suspended sediment load during a flood to the sea or by the water released below the dam. This water in the sedimentology texts called "hungry water", because it has sufficient energy to transport sediment (Committee \& Subcommittee, 2017). Sediment returns back to the coastal area by wave and tide, then moved toward land by wind.

2. Transporting sediment by wind directly from dried river (Shayan, S. Akbarian, M. Yamani, M. Sharifikia, M. Maghsoudi, 2014)(Gholami, Dolat, Li, \& Telfer, 2019). 
Mangrove forest: The total area of natural mangrove forests decreased during dam construction (from 1997 to 2003). Dam construction that influenced Mangroves forest in two ways, which are; trapping sediment in reservoirs and using water for human consumption that decreased freshwater flux to the coast (Sukardjo, 1993). The simultaneous increase in NP, PD, ED and decrease in MPS illustrated mangrove forest fragmentation during 1997 and 2003.

The reason of changes in landscape metrics trends after 2003, increase in CA, MPS, LPI and decrease in LSI and ED, was that the mangroves forest was protected as a national conservation area in 2004 by government and after that human-made mangrove forest increased and barren lands changed to mangrove forest(Petrosian et al., 2016). The shape and height of man-made mangrove forests are utterly different from the natural mangrove forest(Mahmoudi1, Petrosian, Kar, \& O. Zakeri, 2014), and it was clear in the survey field. During study period, the shape of mangrove forests patches was becoming more regular that it's the sign of human-made forests.

Despite the high-cost maintenance of the conservative area and planting new seedlings, in some parts of the study area, sand dunes encroaching the mangrove area and aerial roots of natural mangrove forests completely covered by sand dunes, so these parts of natural mangrove forest are damaged and dried (Figure 2). Based on the recent study on sustainability trend of human made mangrove forest in Hormozgan coastal area, unfortunatelly the stability of these forest are very low and classified in highly unstable group(Mahmoudi1 et al., 2014). In this regard, if natural mangrove forest will be decreased with this trend there is no alternative way to support biodiversity and local people (Petrosian et al., 2016).

Buildup lands: CA, NP and PD of residential and mixed Buildup lands class increased during the period of study. Based on the interview with local people, it was related to agricultural and fisheries development and immigration of people to this area during the last decade. Increasing Human settlements creates massive pressure on a coastal ecosystem (Sukardjo, 1993). Also, as the Table 4 shows that built up land-mixed (commercial ports) increased from 2014 to 2018. Hence job opportunities had increased widely. Edge density (ED) surged; this indicates the ratio of the total edge length of all built-up land patches to the total landscape area has substantially improved at the whole landscape trend to the anthropogenic landscape. MPS generally decreased by almost $51 \%$ while, LPI increased by $66 \%$. Although the giant residual patch increased, the new urban centers are growing faster than existing urban areas. In other words, during this period, urban leapfrog has been customarily seen rather than infilling development (Luck \& Wu, 2002).

Riparian vegetation : Seasonal rivers in this arid part support riparian woodland and hydromorphic grassland, and have critical roles in the control of river erosion and supplying habitat for wildlife (Operations et al., 2000).

Riparian vegetation fluctuates because of either reduction or changes in the pattern of water flow in the Jagin River, which might affect the riparian or hydromorphic vegetation. The main reason for the decrease of (888 ha) from 1997 to 2003 was dam construction that cut the flow of water to the river. The average flow rate decreased from $8.9 \mathrm{~m} 3 / \mathrm{s}$ in 1997 to 0.5 in 2003. In 2008, river water right was released regularly, that yield to the increase in riparian vegetation. Since 2008, river water flow was decreasing. The main reasons for decreasing based on the results of the survey field and interviews with local people and managers were: a dramatic increase in agricultural land, illegal extraction of water, and added another consumption of reserved water, supplying drinking water. Based on the interview with a natural resource manager of Jask city and analysis of the temporal maps, the water right during recent years decreased and downstream of Jagin River was dried. In the study area, decision-makers preferred to use reserved water for supplying drinking water and irrigated water. Discharge water to the Jagin River for providing water rights of the downstream ecosystem has a lower preference for those decision-makers.

Simultaneous decreasing in most of the metrics (CA, MPS, LPI, ED and LSI) from 2008 to 2018 presented that patches became smaller with less complex shapes.

Vegetation cover: Increase in NP, PD, ED and LSI, and decrease in MPS, CA, LPI, from 2003 to 2018, indicate that there was habitat fragmentation. This is possibly due to the development of the residential 
area, especially increase in aquaculture land and build up land-mixed (Sukardjo, 1993) between 2014 and 2018.

Shannon's diversity index is frequently used in the determination of landscape diversity (Profile, 2017). From 1997 to 2003 and from 2008 to 2014, even though landscape classes increased, SHDI and heterogeneity decreased. Increasing SHDI from 1987 to 1997, from 2003 to 2008 and between 2014 and 2018, while the number of landscape types in the region did not change, indicating the proportion of the differences between landscape types is becoming more significant, uneven distribution and the landscape heterogeneity increases.

The dynamic monitoring of landscape pattern in 31 years showed that the coastal area downstream of dam landscape pattern changes was as follows:

- landscapes continuously were characterized by anthropogenic pattern features (agriculture land, aquaculture land, built-up land and residential) after the construction of the dam

- Most of the natural vegetation cover decreased and changed to agriculture lands. On the other hand, the sand dune area was extended during the period of the study. One of the most important driving forces of sand dunes activity is wind power (Amir et al., 2014) which can increase by decreasing vegetation cover. Another factor of sand dune activity is drought. Jagin River follow to downstream be decreased continuously after dam construction because of two reasons: accumulate water in the reservoir, and pumping water flows for irrigation. As mentioned above, dried downstream of Jagin River is the source of erosion and can have an important role in charging sand (Gholami et al., 2019). Extension sand dune cause of a lot of concern for human life and natural features.

- After construction of the dam, some parts of the natural mangrove area have been dried because of sand dune extension. Natural resource managers spend a lot of money and time on spreading humanmade mangrove trees. These human-made forests are completely different from natural mangrove forest parts. The sustainability analysis of afforestation zone in the study area based on the five index densities, average height growth, average regeneration, stability of stands and their alteration trend, the total score was very low and it was classified as highly unstable forest(Mahmoudi1 et al., 2014)

- Shannon's diversity index had an increasing trend. It showed that regional landscape heterogeneity increased, and the anthropogenic features more and more controlled the landscape. Moreover, it indicated that the intensity of human disturbances was more and more increasing.

- Rivers legal rights protect them from harmful water projects(Donnell, 2018). Dam construction without considering environmental policy, especially river water right cause of several hierarchical problems: dried river, extensive sand dune, dried mangrove forest, damaged human life, and maybe in future, unbound agriculture land due to influx of sand dune.

\section{Acknowledge}

This work was supported by Iran National Science Foundation (INSF) and the author thanks Iran National Science Foundation (INSF) for this support (No. 93030709).

\section{References}

Acreman, M. (2014). Water and Ecology Linking the Earth's Ecosystems to its Hydrological Cycle . (May).

Alphan, H. (2017). Analysis of landscape changes as an indicator for environmental monitoring. Environmental Monitoring and Assessment , 189 (1). https://doi.org/10.1007/s10661-016-5748-7

Amir, R., Kinast, S., Tsoar, H., Yizhaq, H., Zaady, E., \& Ashkenazy, Y. (2014). Journal of Geophysical Research : Earth Surface The effect of wind and precipitation on vegetation and biogenic crust covers in the Sde-Hallamish sand dunes . 437-450. https://doi.org/10.1002/2013JF002944.Received

Andr, D., Daza, V., Hernando, S., Portz, L., Jos, H., \& Anfuso, G. (2020). Mangrove Forests Evolution and Threats in the Caribbean Sea of Colombia .

Araya, Y. H., \& Cabral, P. (2010). Analysis and modeling of urban land cover change in Setúbal and Sesimbra, Portugal. Remote Sensing ,2 (6), 1549-1563. https://doi.org/10.3390/rs2061549 
Basin, H. R. (2018). Landscape pattern change and associated environmental implications in the LANDSCAPE PATTERN CHANGE AND ASSOCIATED ENVIRONMENTAL . (January 2014), 2015-2018.

Berlanga-robles, C. A., Ruiz-luna, A., Bocco, G., \& Vekerdy, Z. (2011). Ocean \& Coastal Management Spatial analysis of the impact of shrimp culture on the coastal wetlands on the Northern coast of Sinaloa, Mexico. Ocean and Coastal Management , 54 (7), 535-543. https://doi.org/10.1016/j.ocecoaman.2011.04.004

Botequilha-Leitão, A., \& Diáz-Varela, E. (2018). An alternative planning paradigm for coastal landscapes and tourism. Spatial metrics as indicators for planning coastal tourism landscapes. Tourism 85 Management Studies , 14 (1), 45-57. https://doi.org/10.18089/tms.2018.14104

Cai, Y. Bin, Li, H. M., Ye, X. Y., \& Zhang, H. (2016). Analyzing three-decadal patterns of land use/land cover change and regional ecosystem services at the landscape level: Case study of two coastal metropolitan regions, Eastern China. Sustainability (Switzerland) , 8 (8), 1-21. https://doi.org/10.3390/su8080773

Chen, Q., Jia, L., Hutjes, R., \& Menenti, M. (2015). Estimation of aerodynamic roughness length over oasis in the heihe river basin by utilizing remote sensing and ground data. Remote Sensing ,7 (4), 3690-3709. https://doi.org/10.3390/rs70403690

Committee, A., \& Subcommittee, W. I. (2017). Dam Removal Analysis Guidelines for Sediment . (December).

Deng, J. S., Wang, K., Hong, Y., \& Qi, J. G. (2009). Spatio-temporal dynamics and evolution of land use change and landscape pattern in response to rapid urbanization. Landscape and Urban Planning ,92 (3-4), 187-198. https://doi.org/10.1016/j.landurbplan.2009.05.001

Dong, C. K., \& Wang, Z. F. (2010). Analyzing coastal wetland change in the Yancheng National Nature Reserve, Analyzing coastal wetland change in the Yancheng National Nature Reserve, China . (March). https://doi.org/10.1007/s10113-010-0130-8

Donnell, E. O. (2018). Creating legal rights for rivers : Lessons from Australia , New Zealand, and India Creating legal rights for rivers : lessons from Australia, New Zealand, and . (March). https://doi.org/10.5751/ES-09854-230107

El-kawy, O. R. A., Rod, J. K., Ismail, H. A., \& Suliman, A. S. (2011). Land use and land cover change detection in the western Nile delta of Egypt using remote sensing data. Applied Geography , 31 (2), 483-494. https://doi.org/10.1016/j.apgeog.2010.10.012

Feng, Y., Liu, Y., \& Tong, X. (2018a). Spatiotemporal variation of landscape patterns and their spatial determinants in Shanghai, China.Ecological Indicators , 87 (July 2017), 22-32. https://doi.org/10.1016/j.ecolind.2017.12.034

Gbanie, S. P., Griffin, A. L., \& Thornton, A. (2018). Impacts on the urban environment: Land cover change trajectories and landscape fragmentation in post-war Western Area, Sierra Leone. Remote Sensing, 10 (1). https://doi.org/10.3390/rs10010129

Gholami, H., Dolat, M., Li, J., \& Telfer, M. W. (2019). Diverse sources of aeolian sediment revealed in an arid landscape in southeastern Iran using a modi fi ed Bayesian un-mixing model. Aeolian Research , 41 (December 2018), 100547. https://doi.org/10.1016/j.aeolia.2019.100547

Gustafson, E. J. (2019). How has the state-of-the-art for quantification of landscape pattern advanced in the twenty-first century ? Landscape Ecology , 34 (9), 2065-2072. https://doi.org/10.1007/s10980-018-0709-x

Haque, I., \& Basak, R. (2017). The Egyptian Journal of Remote Sensing and Space Sciences Land cover change detection using GIS and remote sensing techniques : A spatio-temporal study on Tanguar Haor, Sunamganj, Bangladesh. 20 , 251-263.

Hu, Y., Huang, J., Du, Y., Han, P., \& Wang, J. (2015). Monitoring wetland vegetation pattern response to water-level change resulting from the Three Gorges Project in the two largest freshwater lakes of China.Ecological Engineering , 74 , 274-285. https://doi.org/10.1016/j.ecoleng.2014.10.002 
Ju, D. C., Arnaldo, R., Gomes, T., Fontes, R., \& Mcmanus, C. M. (2017).Landscape-fragmentation change due to recent agricultural expansion in the Brazilian Savanna, Western Bahia, Brazil . 411-423. https://doi.org/10.1007/s10113-016-0960-0

Li, Y., Zhu, X., Sun, X., \& Wang, F. (2010). Landscape effects of environmental impact on bay-area wetlands under rapid urban expansion and development policy: A case study of Lianyungang, China.Landscape and Urban Planning , 94 (3-4), 218-227. https://doi.org/10.1016/j.landurbplan.2009.10.006

Liu, J. Y. S., \& Wang, C. (2014). Forest pattern dynamics and landscape connectivity changes in the Manwan Basin after dam construction in the Lancang River, China Forest pattern dynamics and landscape connectivity changes in the Manwan Basin after dam construction in the Lancang River, China . (January). https://doi.org/10.1007/s11355-013-0217-8

Lu, J. (2018). Landscape Ecological Changes of Large Dams and Reservoir in China . (May). https://doi.org/10.5141/JEFB.2004.27.1.009

Luck, M., \& Wu, J. (2002). A gradient analysis of urban landscape pattern : a case study from the Phoenix metropolitan region, Arizona, USA . (1925), 327-340.

M. C. Iwuji, C. P. Iheanyichukwu, J. D. Njoku, F. I. Okpiliya, S. O. Anyanwu, G. T. A. and K. O. E. U. (2017). Assessment of Land Use Changes and Impacts of Dam Construction on the Mbaa Assessment of Land Use Changes and Impacts of Dam Construction on the Mbaa River, Ikeduru ,..Journal of Geography, Environment and Earth Science International , 13(1) (December). https://doi.org/10.9734/JGEESI/2017/34984

Mahamane, M., Hochschild, V., Schultz, A., \& Kuma, J. (2015). Monitoring Desertification in the Tillabery Landscape (Sahel Region) using Change Detection Methods and Landscape Metrics.International Journal of Applied Research , 1 (10), 315-321. Retrieved from www.allresearchjournal.com

Mahmoudi1, B., Petrosian, H., Kar, A. D., \& O. Zakeri. (2014). Analysis of sustainability trend in restoration and development of mangroves in Hormozgan coastal line. Iranian Journal of Forest and Poplar Research, 22, 259-269.

Manson, F. J., Loneragan, N. R., \& Phinn, S. R. (2003). Spatial and temporal variation in distribution of mangroves in Moreton Bay, subtropical Australia : a comparison of pattern metrics and change detection analyses based on aerial photographs . 57 , 653-666. https://doi.org/10.1016/S0272-7714(02)00405-5

Moser, D., Zechmeister, H. G., Plutzar, C., Sauberer, N., \& Grabherr, G. (2002). Landscape patch shape complexity as an effective measure for plant species richness in rural landscapes Landscape patch shape complexity as an effective measure for plant species richness in rural landscapes . (October). https://doi.org/10.1023/A

Muller, S. V, Walker, D. A., Nelson, F. E., Auerbach, N. A., Bockheim, J. G., Guyer, S., \& Sherba, D. (1998). Accuracy Assessment of a Land-Cover Map of the Kuparu $k$ River Basin, Alaska: Considerations for Remote Regions . 64 (6), 619-628.

Narumalani, S., Mishra, D. R., \& Rothwell, R. G. (2004). Change detection and landscape metrics for inferring anthropogenic processes in the greater EFMO area. Remote Sensing of Environment ,91 (3-4), 478-489. https://doi.org/10.1016/j.rse.2004.04.008

Operations, A. M., Caused, H., Ecological, S., In, C., To, O. W., River, P., .. Our, O. F. (2000). Alterations of Riparian Ecosystems Caused by River Regulation . 50 (9), 783-792.

Ouyang, W., Skidmore, A. K., Hao, F., Toxopeus, A. G., \& Abkar, A. (2009). Landscape and Urban Planning Accumulated effects on landscape pattern by hydroelectric cascade exploitation in the Yellow River basin from 1977 to 2006 . 93 , 163-171. https://doi.org/10.1016/j.landurbplan.2009.07.001

Pa, F. (2005). The Environmental Impact of Shrimp Aquaculture : Causes, Effects, and Mitigating Alternatives . 28 (1), 131-140. https://doi.org/10.1007/s002670010212 
Pak, A., \& Farajzadeh, M. (2007). Iran's Integrated Coastal Management plan : Persian Gulf, Oman Sea , and southern Caspian Sea coastlines \$ . 50 , 754-773. https://doi.org/10.1016/j.ocecoaman.2007.03.006

Petrosian, H., Kar, A. D., Ashrafi, S., \& Feghhi, J. (2016). Investigating environmental factors for locating mangrove ex-situ conservation zones using GIS spatial techniques and the logistic regression algorithm in mangrove forests in Iran. Polish Journal of Environmental Studies , 25 (5), 2097-2106. https://doi.org/10.15244/pjoes/62640

Profile, S. E. E. (2017). Theoretical view of the Shannon index in the evaluation of landscape diversity $R$ a d e k Du še k, R e nata P o p e l ková . (September). https://doi.org/10.14712/23361980.2015.12

Rashidi, M., \& Gholami, M. (2008). Review of Crop Water Productivity Values for Tomato , Potato , Melon , Watermelon and Cantaloupe in Iran. (September 2014).

Reading, A. (2001). Landscape Metrics for Categorical Map Patterns . 2001 (Chapter 5), 1-77.

Saura, S., \& Martinez-Millan, J. (2001). Sensitivity of landscape pattern metrics to map spatial extent. Photogrammetric engineering and remote sensing.

Shayan, S. Akbarian, M. Yamani, M. Sharifikia, M. Maghsoudi, M. (2014). Analysis of Sand Masses Morphogenetic in Makran Coastal Plain.Environmental Erosion Researches , 13 , 62-78.

Singh, S. K., Srivastava, P. K., Szabó, S., Petropoulos, G. P., Gupta, M., \& Islam, T. (2017). Landscape transform and spatial metrics for mapping spatiotemporal land cover dynamics using Earth Observation data-sets. Geocarto International , 32 (2), 113-127. https://doi.org/10.1080/10106049.2015.1130084

Sinha, P., Kumar, L., \& Reid, N. C. H. (2016). Rank-Based Methods for Selection of Landscape Metrics for Land Cover Pattern Change Detection. (February). https://doi.org/10.3390/rs8020107

States, U., Nrothwest, P., \& Technical, G. (1995). FRAGSTATS : Spatial Pattern Analysis Program for Quantifying Landscape Structure . (August).

Steinhardt, U. T. A., \& Lehmann, S. (2001). Landscape Metrics for Assessment of Landscape Destruction and Rehabilitation . 27 (1), 91-107. https://doi.org/10.1007/s002670010136

Sudhakar Reddy, C., Manaswini, G., Jha, C. S., Diwakar, P. G., \& Dadhwal, V. K. (2017). Development of National Database on Long-term Deforestation in Sri Lanka. Journal of the Indian Society of Remote Sensing , 45 (5), 825-836. https://doi.org/10.1007/s12524-016-0636-8

Sukardjo, S. (1993). The Present Status of the Mangrove Forests in the Northern Coast of West Java with Special Reference to the Recent Utilization. Southeast Asian Studies, 31.

Tran, L. X., \& Fischer, A. (2017). Spatiotemporal changes and fragmentation of mangroves and its effects on fish diversity in Ca Mau Province (Vietnam). Journal of Coastal Conservation ,21 (3), 355-368. https://doi.org/10.1007/s11852-017-0513-9

Vaz, E. (2014). Managing urban coastal areas through landscape metrics: An assessment of Mumbai's mangrove system. Ocean and Coastal Management , $98 \quad, \quad 27-37$. https://doi.org/10.1016/j.ocecoaman.2014.05.020

Wohl, E., \& Brian, P. (2015). The Natural Sediment Regime in Rivers : Broadening the Foundation for Ecosystem Management . (March). https://doi.org/10.1093/biosci/biv002

Wu, H., Zeng, G., Liang, J., Chen, J., Xu, J., Dai, J., .. Ye, S. (2017). International Journal of Applied Earth Observation and Geoinformation Responses of landscape pattern of China's two largest freshwater lakes to early dry season after the impoundment of Three-Gorges Dam. International Journal of Applied Earth Observations and Geoinformation , 56 , 36-43. https://doi.org/10.1016/j.jag.2016.11.006

$\mathrm{Xu}, \mathrm{X}$., \& Min, X. (2013). Quantifying spatiotemporal patterns of urban expansion in China using remote sensing data. Cities , 35 , 104-113. https://doi.org/10.1016/j.cities.2013.05.002 
Zang, Z., Zou, X., Song, Q., \& Yao, Y. (2019). Analysis of the spatiotemporal correlation between vegetation pattern and human activity intensity in Yancheng coastal wetland, China 1 . 100 (June), 87-100.

Zewdie, W., \& Csaplovics, E. (2016). Identifying Categorical Land Use Transition and Land Degradation in Northwestern Drylands of Ethiopia . https://doi.org/10.3390/rs8050408

Zhang, F., Kung, H., \& Johnson, V. C. (2017). Assessment of Land-Cover / Land-Use Change and Landscape Patterns in the Two National Nature Reserves of Ebinur Lake Watershed, Xinjiang, China . https://doi.org/10.3390/su9050724

Zhao, H., Cui, B., Zhang, H., Fan, X., Zhang, Z., \& Lei, X. (2010). A landscape approach for wetland change detection (1979-2009) in the Pearl River Estuary. Procedia Environmental Sciences , 2 (5), 12651278. https://doi.org/10.1016/j.proenv.2010.10.137

\section{Hosted file}

Figures.docx available at https://authorea.com/users/355291/articles/478600-landscapeanalysis-over-30-years-to-assess-the-impact-of-river-damming-on-natural-ecosystem 